\title{
Cumulative effect of needle cast on Scots pine saplings
}

\author{
Āris Jansons", Una Neimane, Kaspars Polmanis, \\ Astra Zaļuma, Tālis Gaitnieks and Imants Baumanis
}

\begin{abstract}
Jansons, Ā., Neimane, U., Polmanis, K., Zaluma, A., Gaitnieks, T., Baumanis, I. 2016. Cumulative effect of needle cast on Scots pine saplings. - Forestry Studies | Metsanduslikud Uurimused 65, 5-15. ISSN 1406-9954. Journal homepage: http:/ / mi.emu.ee/ forestry.studies
\end{abstract}

\begin{abstract}
Premature needle cast, affecting the needles on one-year old shoots, thus shrinks the size of green crown of Scots pines, and can cause reduction of increment or even death of trees, especially during first years of their growth. Aim of our study was to evaluate the lasting impact of pathological needle cast to young Scots pines and its implications for tree breeding. Assessment of needle cast damages in 5 grade scale and measurements of height were done repeatedly in Scots pine open pollinated progeny trial, consisting of 65 families, located in central part of Latvia. Proportion of saplings with different level of needle cast damage differed significantly between the years of impact: severely damaged were $51 \%, 30 \%$ and $17 \%$ of saplings in growing seasons 4,5 and 6 , respectively. Both the needle cast damage grade at current growing season, as well as height of the sapling before the needle cast infection (at the end of the third growing season) had a significant effect on its grade of needle cast damages in the next growing season. Cumulative level of needle cast damages at the age 4 to 6 years had significant negative effect on height of the saplings at the age of 12 years both at individual tree and family mean level, as well as on survival. Selection of best growing families in such trial would also lead to selection of genotypes least affected by the disease.
\end{abstract}

Key words: Lophodermium spp., fungal disease, repeated infection, survival.

Authors' address: Latvian State Forest Research Institute "Silava", 111 Rigas st., Salaspils, LV2169, Latvia; *e-mail: aris.jansons@silava.lv

\section{Introduction}

Scots pine (Pinus sylvestris L.) is one of the most important forest tree species in Latvia, it dominates in $34 \%$ of forests (Report of State Forest Service, 2015). Annual planting area reaches around 6,000 ha, that is $18-21 \%$ of the total forest regeneration area and about half (43-51\%) from total planted area (Report of State Forest Service, 2015). Until the 90-s of the previous century planting of relative large 2-year-old bare root pine seedlings in high initial density $(7,000-10,000$ trees per ha) was the common forestry practice in Latvia (Bušs \& Mangalis, 1971). Such density allowed improving the quality of stand by natural selection and high intensity of thinnings; thus trees with defects or unfavourable stem and branch traits (at least party genetically determined) were removed. Due to intensive tree breeding, leading to improvement of productivity and quality of trees (Jansons, 2005; Jansons et al., 2006; Jansson et al., 2016) as well as development of plant production technologies, leading to better survival and initial growth of planted trees, nowadays $3,000-3,500$ seedlings per ha are planted. It means that resistance of tree to the impact of different negative environmental factors is becoming increasingly more important. Especially if considering, that mostly $(74 \%)$ one-year 
old containerized seedlings with relatively small size (height 8-20 cm, root collar diameter 2-3 $\mathrm{mm}$ ) are used for planting (Report of LVM, 2015). Therefore, notable investments had been made into protection of the plants against dendrophagous insects (mainly - large pine weevil Hylobius abietis L.) both in nursery and in forest, as well as in protection against browsing damages by cervids (Report of LVM, 2015). However, so far not much has been done to improve disease-resistance of trees against fungi. The impact of fungi might be increasing in future due to arrival of new invasive species in particular area (Drenkhan \& Hanso, 2009) or due to increase of impact of already common fungi, caused by more favourable climatic conditions. Lophodermium needle cast had been a continuous threat to young Scots pine in nurseries and plantations across the northern Baltics and Scandinavia for a long time (Stenström \& Arvidsson, 2001; Hanso \& Drenkhan, 2007; Lilja et al., 2010; Bednářová et al., 2013). Besides, damage to forest stands could be the result of a complex of pathogens, for example, Dothistroma needle blight is often associated with Lophodermium needle cast at tree and stand level (Drenkhan et al., 2016). In Latvia Dothistroma septosporum (Dorog.) M. Morelet. was recorded in 2008 (Drenkhan \& Hanso, 2009; Drenkhan et al., 2016). Also Mycosphaerella dearnessii M.E. Barr, Cyclaneusma minus (Butin) DiCosmo, Peredo \& Minter, Diplodia pinea ((Desm.) J.J. Kickx) can cause needle damages of pines in Europe (Drenkhan \& Hanso, 2009; Bednářová et al., 2013; Adamson et al., 2015). Importance of foliar diseases is increasing due to gradual reduction of use of fungicides in forests (especially in relation to forest certification) as well as more favourable climatic conditions for this disease (Jansons et al., 2012).

Selection for resistance in tree breeding programs can reduce the susceptibility of planted trees (Eriksson et al., 2013). Differences of resistance of geographically distinct European provenances of Scots pine have been analysed, and the decreased resistance was detected for the most southern and western provenances; accordingly, the progenies of the northern and eastern origin suffered the least from needle cast infection (Björkmann, 1964; Squillace et al., 1975; Baumanis, 1983; Ostry \& Nicholls, 1989; Kuzmina \& Kuzmin, 2008; Vuorinen, 2008). Differences in susceptibility between the families within a provenance also had been detected (Baumanis, 1993; Jansons et al., 2008) indicating a potential for selection. However, as more traits are included into selection index, as smaller the improvement for each particular trait might become. Therefore it is important to assess the short and long-term impact of the disease before including it into selection program. It is known, that Lophodermium needle cast not only contributes to the mortality of young Scots pines, but also reduces growth of trees (Squillace et al., 1975; Martinsson, 1979; Jansons et al., 2008; Hanso \& Drenkhan, 2012), like any other cause of defoliation. For instance, decline of the increments caused by defoliation by sawfly was reported for Scots pine in Latvia (Šmits et al., 2008) and in Finland (Lyytikäinen-Saarenmaa, 1999). Several authors pointed out that impact of defoliation on growth depends not only on the intensity of defoliation, but also other environmental factors (Kulman, 1971). Thus higher stress level to the young trees in future climatic conditions (e.g. due to altered precipitation regime) might increase the impact of the needle cast. Previous studies mostly had addressed short-term (1-3 year) impact of the disease; however, in forestry information on longer-term consequences of any influences is important. Therefore, aim of our study was to evaluate the lasting impact of pathological needle cast on young Scots pines and its implications for tree breeding. We hypothesized that impact of needle cast at young age (4-6 years) would have a significant negative effect on tree height and survival at selection age (12 years) and thus choice of best-growing families at this age would be sufficient to simultaneously select also for genotypes least affected by the disease. 


\section{Material and Methods}

The study was carried out in open pollinated progeny trial of Scots pine. Trial consists of 65 families, it was established in central part of Latvia, near Daugmale $\left(56^{\circ} 47^{\prime} \mathrm{N}\right.$, $24^{\circ} 30^{\prime} \mathrm{E}$ ), in Vacciniosa forest type (Bušs, 1976) using one-year-old seedlings. Each family was planted in eight replicates of 10 trees (two rows of five trees), planting density $2 \times 1.5 \mathrm{~m}$. Tree height at age 3, 4, 5, 6, 7 and 12 years was measured. Crown closure of pines has been just started, and no thinning was done yet. Mean values $( \pm 95 \%$ confidence intervals) were calculated for tree height at different age, and Pearson's correlation was used to asses relationship between these values. To estimate the role of tree height in its reaction to needle cast infection trees were divided in two approximately equal groups depending on their "initial" height (i.e. height at the end of the $3^{\text {rd }}$ growing season, before the first needle cast damages): (1) trees which height exceeded average, further in text "high trees" and (2) trees which height was equal or less than average, further in text "low trees".

Premature needle cast was first observed in trial in the $4^{\text {th }}$ growing season and needle cast damage assessment was done at five grade scale in the June of the $4^{\text {th }}, 5^{\text {th }}$ and $6^{\text {th }}$ growing seasons (years 2008, 2009 and 2010, respectively), according to proportion of damaged needles on the previous season's terminal shoot: Grade 1 corresponded to $0-5 \%$, Grade 2 to $6-35 \%$, Grade 3 to $36-65 \%$, Grade 4 to $66-95 \%$ and Grade 5 to $96-100 \%$ of the damaged needles. To assess the cumulative effect of disease in 3 successive years, the sum of 3 grades (obtaining values from 6 to 15) was used for each tree, denoting them as Total Grade. The proportion of severely damaged trees assessed by Total Grade $>9$ was calculated per family. At the family mean level, linear regression was used to estimate the effect of the proportion of severely damaged trees to the height. The differences of tree height among Total Grades as well as among families were assessed using one way analysis of variance. The Chi squared test was used to evaluate (1) differences of trees' distribution in damage Grades among 3 years of assessments; (2) differences in trees' shifting process from one Grade in assessment of n-season to another Grade in assessment of $n+1$ season among high trees and low trees; (3) differences of survival among the Total Grades. At the individual tree level, relations between the Grades of current and previous season were assessed using Spearman rank correlation. At individual tree level, also the effect of Total Grade and genotype (family) to tree height at age 12 was estimated by generalized linear model (GLM) using tree height at age 3 as covariate.

\section{Results and Discussion}

The proportion of trees with different needle cast damage Grades differed significantly between the years of needle cast infection (Figure 1): severely damaged (Grade $\geq 4$ ) were $51 \%, 46 \%$ and $17 \%$ of trees in growing seasons 4,5 and 6 , respectively, indicating that damage level has been decreased in period 2008-2010. These results are in agreement with studies in the south and central Estonia, where in 2008 epidemic of Lophodermium seditiosum Minter, Staley \& Millar was noted (Drenkhan \& Hanso, 2009). Lophodermium needle cast epidemic is often followed by several intermediate years, during which pines can (at least to some extent) renew their foliage, produce and relocate resources to the new growth or stores (Drenkhan \& Hanso, 2009). On the contrary, Martinsson (1979), analysing resistance of Scots pine to Lophodermium needle cast for 3 successive years (1974-1976) at the same age of trees as in our study, observed the increase of damage level. He explained it as inability of weakened trees to grow out of the zone of strongest influence of the disease (closer to ground), as well as by the increase of the produced amount of pathogens' spores from a repeatedly infected 


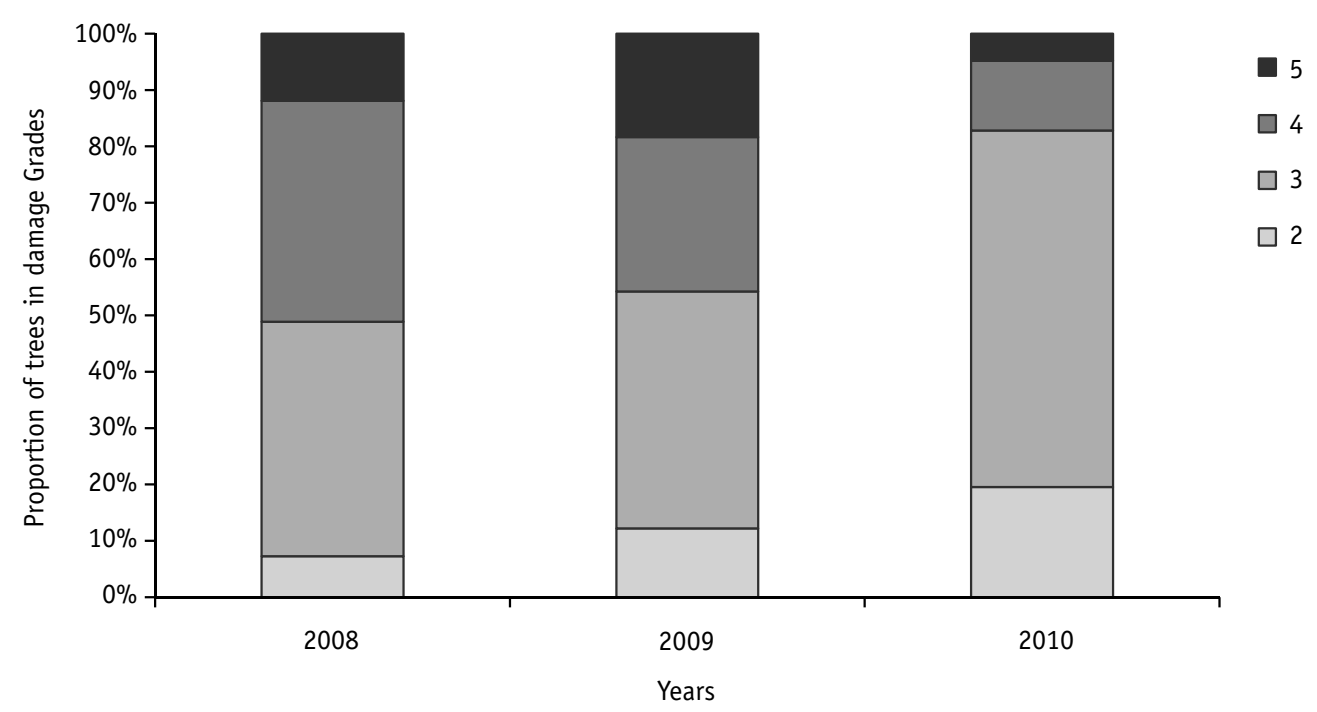

Figure 1. Distribution of trees in different needle cast damage Grades (2-5) in 2008-2010 (the 4th, 5th and 6 th growing seasons, respectively).

needles. In our study the strong positive relationship $(p<0.001)$ between the tree damage Grade in the $4^{\text {th }}$ and $5^{\text {th }}, 5^{\text {th }}$ and $6^{\text {th }}$, as well as $4^{\text {th }}$ and $6^{\text {th }}$ seasons has been detected, reaching $r_{s}=0.55,0.53,0.37$, respectively. Similarly, strong positive correlations were found between damages in several successive years for Scots pine affected by Lophodermium needle cast (Martinsson, 1979), and for 2-6-years old Monterey pine (Pinus radiata D. Don) influenced by Dothistroma needle blight Dothistroma pini Hulbary (van der Pas, 1981).

Martinsson (1979) emphasized that in the third assessment season trees with little damages had been less affected also two years earlier, unlike the more severely damaged trees which assessment varied notably in the first observation season. Similarly in our trail inter-annual link between damage level (Grade) of a tree had been found. Moreover, this was influenced by tree height. The shifting of trees from damage Grade in the $4^{\text {th }}$ season to damage Grade in the $5^{\text {th }}$ season differed significantly $(p<0.01)$ between high trees and low trees: the proportion of trees which had been less damaged in the $5^{\text {th }}$ season than in the $4^{\text {th }}$ was twice greater for high trees than for low (34 and $17 \%$, respectively), even so the proportion of trees which kept the same damage Grade in both seasons was similar in both tree height groups ( $50 \%$ and $45 \%$, respectively). Similarly, significant $(p<0.001)$ differences between tree height groups in the proportion of trees changing their damage grade (higher, the same, lower) from one season to another were found also in analysis of tree in each of the $4^{\text {th }}$ season's damage Grade separately (Figure 2). For instance, from high trees (H1) with damage Grade 3 in $4^{\text {th }}$ season majority $(85 \%)$ had the same or lower damage Grade in the next season, while from low trees (H2) with the same grade in $4^{\text {th }}$ season the proportion of such tress was notably smaller (56\%).

Similar tendencies were found for changes in damage Grade between $5^{\text {th }}$ and $6^{\text {th }}$ growing season, although differences between the groups of high and low trees were less pronounced, and were statistically significant $(p<0.001)$ only for trees 


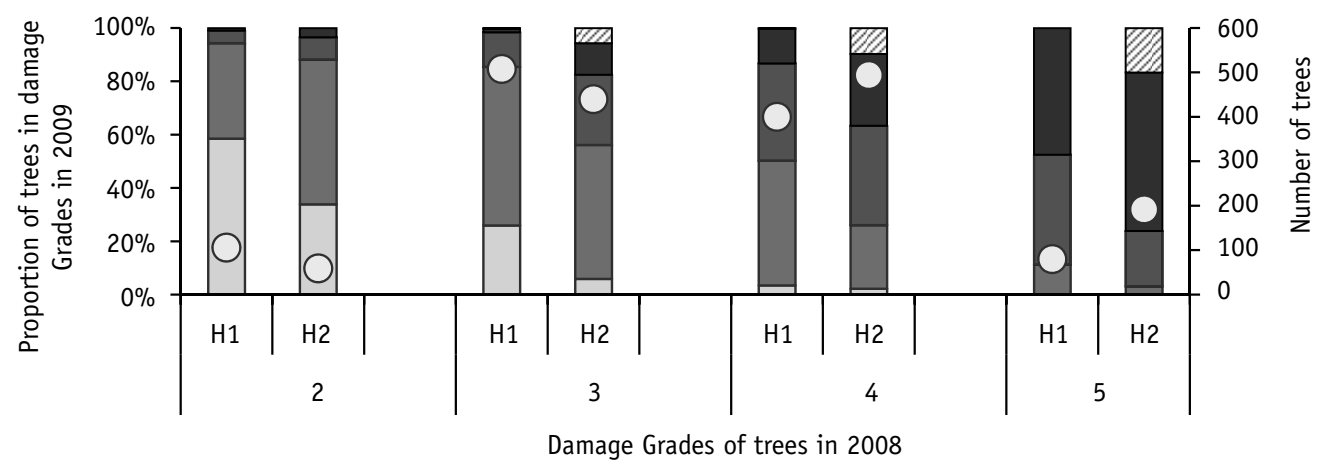

$\square 2 \square 3 \square 4 \square 5 \square$ Dead O Number of trees

Figure 2. Distribution (shift) of high trees (H1) and low trees (H2) in different damage Grades (2-5) in the 5th growing season (2009) according to their damage Grade (2-5) in the 4th growing season (2008).

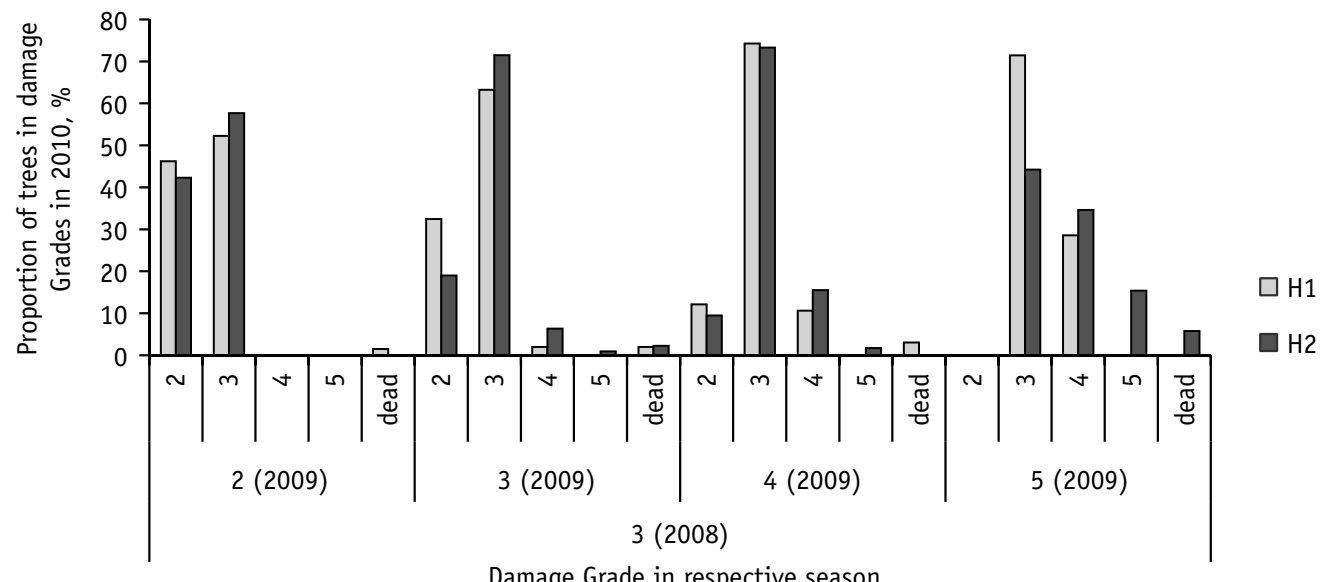

Figure 3. Distribution of trees in different damage Grades (2-5, and dead) in the 6th growing season (2010) according to their damage Grade (2-5) in the 5th growing season (2009). High trees (H1) and low trees ( $\mathrm{H} 2)$ of the damage Grade 3 in the 4th season's assessment are displayed.

in most frequently found damage Grades (3 and 4). Likewise, for majority of trees (damage Grades 3 in $4^{\text {th }}$ and $5^{\text {th }}$ growing season or damage Grade 4 in both growing seasons) damage Grade in the $6^{\text {th }}$ season was dependent on damage Grades in each of two previous seasons as well as significantly $(p<0.01)$ affected by the initial height group (Figure 3).
Strong negative cumulative impact of pathological needle cast on survival was observed (Figure 4): mortality for trees which had the most severe damages in 3 consecutive years (Total Grade 15) reached 85\% at age of 12 years. Contrary, none of the least damaged trees (Total Grade 6) had died during the study period; differences of survival among Total Grades were significant $(p<0.001)$. It 


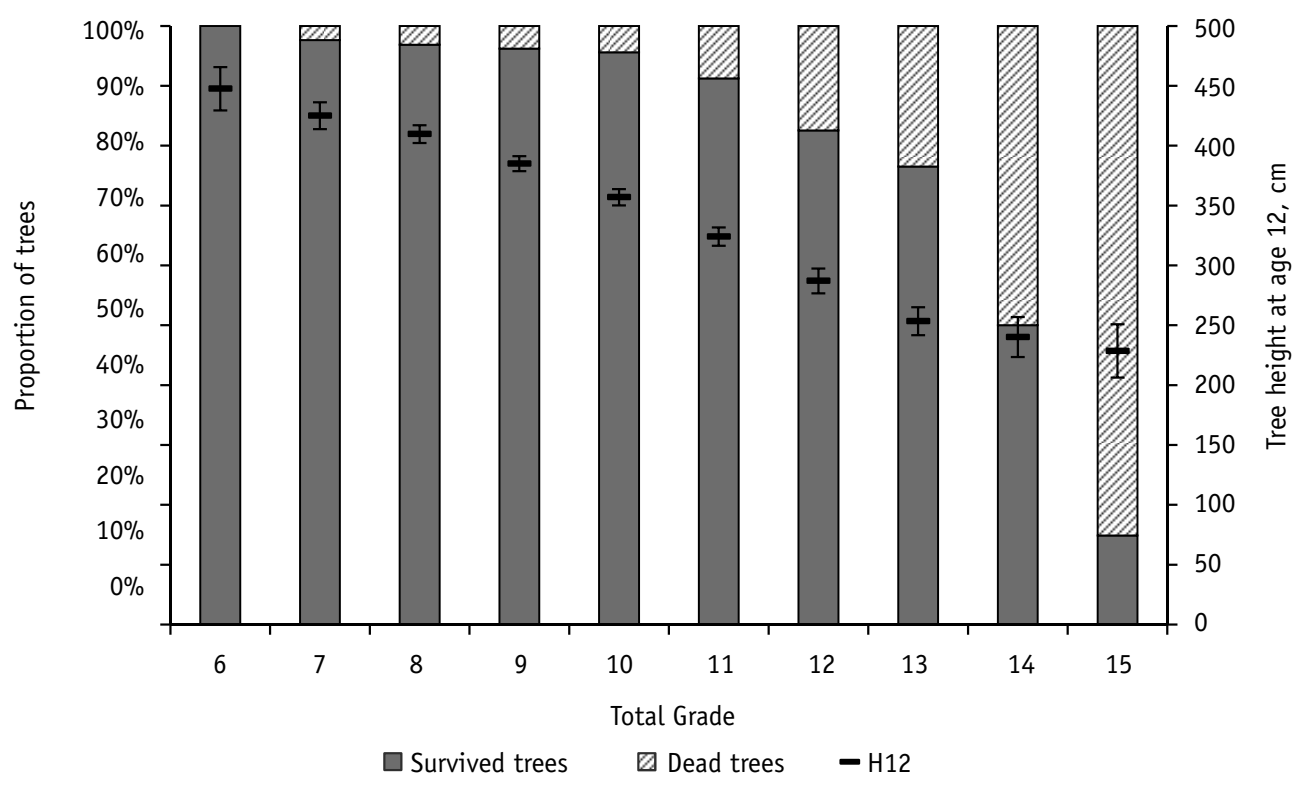

Figure 4. Distribution of survived and dead trees, and tree height ( $\mathrm{H} 12 ; \pm$ confidence interval) according to Total Grades (6-15) at the age of 12 years.

indicates that trees weakened by needle cast had become more exposed to the negative impact to any abiotic or biotic factors such as competition for moisture, nutrients and light, impact of different fungus and insects etc. and consequently died.

Impact of needle cast could be altered by small initial height of trees in the trial (Table 1). Height of trees at age 3 was only $18.5 \pm 0.31 \mathrm{~cm}$ and was a result of both small size of seedlings at the planting moment (length of above-ground part did not exceed $10 \mathrm{~cm}$ ) and also by unfavourable environmental conditions - severe drought period from mid-April till the end of June in the first growing season. Furthermore, the soil preparation method (deep furrows) was not appropriate for the sandy soil in the area of the trial, and seedlings were at least partly covered with moving sand during first growing season.

Correlations between height of individual trees at different age were positive, strong and statistically significant $(p<0.001$ for all values). Though Pearson's correlation coefficients between height at the age 4 and height at later measurements were slightly higher than between height at the age 3 and later measurements. Tree height measured before the needle cast infection (i.e. at age 3) and the current tree height (i.e. at age 12) was used in further analysis of relations between tree height and needle cast damages.

Mean height of trees differed significantly $(p<0.001)$ among the Total Grades - less severely damaged trees were higher than more severely damaged trees. Height of trees which had relatively less suffered from needle cast (Total Grade $\leq 9$ ) was $402 \pm 4.4$ $\mathrm{cm}$, while more damaged trees (Total Grade $>9$ ) were notably and significantly $(p<0.001)$ lower $(320 \pm 4.7 \mathrm{~cm})$. It is in agreement with previous studies, demonstrating significant impact of needle cast fungus $L$. seditiosum on both height and radial increment of Scots pine (Squillace et al., 1975; Martinsson, 1979; Wühlisch \& Stephan, 1986; Hanso \& Drenkhan, 2012). This impact 
Table 1. Correlation between tree height at different age.

\begin{tabular}{cccc}
\hline \multirow{2}{*}{$\begin{array}{c}\text { Age of trees, } \\
\text { years }\end{array}$} & $\begin{array}{c}\text { Height } \pm \text { confidence interval, } \\
\mathrm{cm}\end{array}$ & \multicolumn{2}{c}{ Pearson correlation coefficient } \\
\cline { 3 - 4 } & $18.5 \pm 0.31$ & with height at age 3 & with height at age 4 \\
\hline 3 & $36.9 \pm 0.57$ & 0.85 & - \\
5 & $60.3 \pm 0.97$ & 0.74 & - \\
6 & $94.1 \pm 1.42$ & 0.65 & 0.95 \\
7 & $126.0 \pm 1.77$ & 0.62 & 0.88 \\
12 & $358.2 \pm 3.74$ & 0.51 & 0.85 \\
\hline
\end{tabular}

has been explained by the loss of nutrients stored in the shedding (affected) needles already relatively early in the season. Similar negative effect had been observed also in case of defoliation due to other causes e.g. sawfly feeding (Lyytikäinen-Saarenmaa, 1999). Current year needles, which mature after the shoot elongation, cannot support the current year height increment and can only partly support the radial increment (Clark, 1961; Ericsson et al., 1980), thus only the second and third year needle sets influence the current year growth significantly (Drenkhan et al., 2006; Kurkela et al., 2009). Therefore the assessment of proportion of the lost (damaged) needles of the previous season's height increment, as used in our study, would provide information on the direct link between disease and growth of tree.

Cumulative impact of repeated defoliation on tree growth and, eventually, also survival had been explained not only by the mentioned direct effect, but also indirect (secondary) influences. Repeated defoliation leads to lower production of carbohydrates and thus: (1) gradual depletion of their reserves (Ericsson et al., 1980). Impact of this effect is more pronounced for smaller trees (Shaw \& Toes, 1977); (2) decreasing amount of carbohydrates allocated to the roots of the tree, negatively affecting their development and absorption of nutrients and water (van der Pas, 1981). Impact of secondary effects are manifested with time-lag in com- parison to the progress of the influence e.g. disease can be prolonged in comparison to the duration of the direct influence (Lyr \& Hoffmann, 1967; Ericsson et al., 1980; van der Pas, 1981). This had been demonstrated by Hanso \& Drenkhan (2012): in analysis of long-term historical data they found significant height growth decrease for 3-11-years old Scots pine during the Lophodermium needle cast epidemic year and two consecutive years. Also Kurkela et al. (2009) in the analysis of data from 12-year-old provenance trial concluded, that $50 \%$ needle loss resulted in height increment decrease by $35 \%$ in three successive years. Even five-year recovery period was needed for Sitka spruce after defoliation by European spruce sawfly, causing the reduction of height increment by $24-49 \%$ (Williams et al., 2003).

Prolonged influence of the disease leads to reduced total tree height also a number of years after the impact of the disease: differences among Total Grades in our trial were notable and significant $(p<0.01)$ both for group of trees with low and high initial height (Figure 5). Initially higher trees after being repeatedly severely damaged (great values of Total Grade, e.g. 15) were lower at the age of 12 years than less damaged (e.g. Total Grade 6) initially smaller trees $(222 \pm 31.3 \mathrm{~cm}$ and $437 \pm 35.8 \mathrm{~cm}$, respectively). More pronounced decrease in number of trees (survival) was observed for group with lower initial height and, simultaneously, with greater Total damage Grade. In 

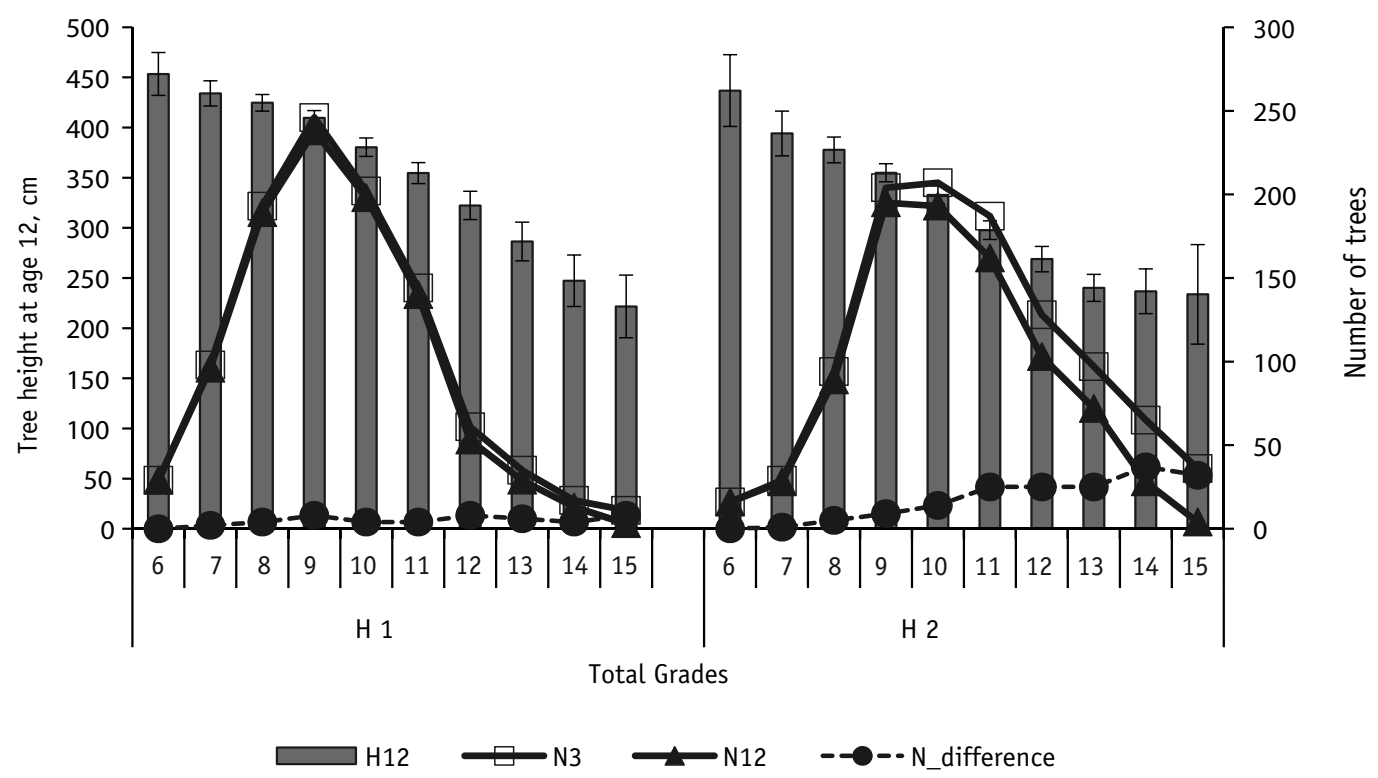

Figure 5. Number of trees at the age of 3 and 12 years (N3 and N12, respectively), difference between them ( $\mathrm{N} \_$difference), and tree height at the age of 12 years ( $\mathrm{H} 12 ; \pm$ confidence interval) according to Total Grades (6-15) for high trees (H1) and low trees (H2).

some cases, needle damage is intensified by attack of several pathogens, for example, in Estonia the epidemic of L. seditiosum converged with the serious spread of $D$. septosporum in young $P$. sylvestris plantations (Drenkhan \& Hanso, 2009).

A similar approach to estimate the differences in impact of disease depending on dimensions of trees was used by Shaw \& Toes (1977) for Monterey pine at age 8-10 years, damaged by D. pini. Cumulative diameter increment of uninfected, moderately and heavily infected trees was compared. Greater impact of the same infection level on trees belonging to group with small initial diameter than to trees in group with large initial diameter was found. In our study the height of high trees exceeded that of low trees in each of Total damage Grade, these differences were statistically significant $(p<0.05)$ for Total Grades 7-13.

Besides, when comparisons within size groups were carried out, Shaw \& Toes (1977) denoted that small trees were dam- aged more severely: for large trees differences in radial increment after the impact between uninfected and moderately infected trees were $17 \%$, and between moderately and heavily infected - 38\%, while the differences for small trees were greater: $50 \%$ and $54 \%$, respectively. In our study differences in Total Grade impact on tree height for high and low trees were less pronounced. These differences might be due to analysed traits, tree species or additional impact of meteorological conditions of particular years and damages caused by other pathogens.

Tree height at the age of 12 years in our trial was affected not only by the level of needle cast damage (Total Grade), but also significantly $(p<0.001)$ influenced by genetics (family) (Figure 6). It was confirmed by GLM analysis for individual trees using initial height (at the age 3) as covariate: final (12-year) height was significantly $(p<0.001)$ influenced both by the Total Grade and the family $\left(R^{2}=0.56\right)$. Mean val- 


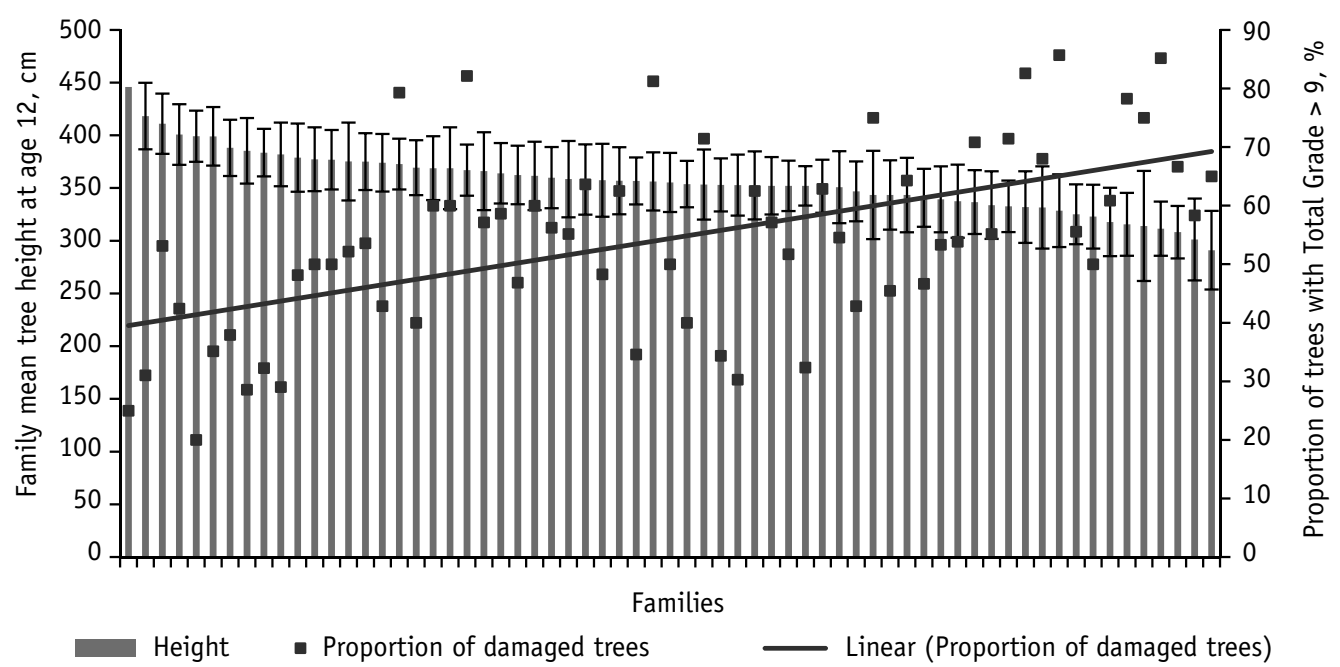

Figure 6. Relation between tree height ( \pm confidence interval) at the age of 12 years and proportion of damaged trees with Total Grade $>9$ at the family mean level.

ues for families ranged from $291 \pm 37.3 \mathrm{~cm}$ to $446 \pm 26.3 \mathrm{~cm}$. The proportion of severely damaged trees (Total Grade > 9) per family ranged from $20 \%$ to $86 \%$.

Similarly, strong genetic (family) effect was found for height and resistance to Lophodermium needle cast by Squillace et al. (1975) for 2-8-years old Scots pine in Netherlands, as well as by Stephan \& Krusche (1986) for 9-year old Scots pine in Germany. Notable genetic variation in symptoms of Swiss needle cast (Phaeocryptopus gaeumannii (Rohde) Petrak) infection for Douglas-fir (Pseudotsuga menziesii (Mirbel) Franco) was found and author suggested, that families with higher tolerance (defined as continued tree growth in the presence of high disease pressure) could be selected (Johnson, 2002). Prospect to improve the tolerance via tree breeding was confirmed by relatively high heritability of this trait (Temel, 2002). However, economic feasibility of selection for resistance against, presumably, numerous diseases needs to be addressed before its inclusion into selection index. Family mean correlation between the proportion of trees estimated by Total Grade $>9$ per family and tree height before the first infection (initial height) was moderate and lower than correlation between this proportion and final (12-year) height $(r=-0.35$ and $r=-0.58$, respectively, $p<0.001$ ), demonstrating the lasting impact of the disease.

\section{Conclusions}

Size of Scots pine tree before the infection as well as genetics (family) determines the needle cast impact (proportion of the needles damaged) both at first and repeated occasions (years) with incidence of the disease. Impact of the diseases at the $4^{\text {th }}-6^{\text {th }}$ growing season significantly affects tree height at $12^{\text {th }}$ growing season. Therefore, if the pathological needle cast has affected the trial, selection of faster growing families with higher survival at the age of 12 years would ensure also selection of genetic material less affected by the disease. 
Acknowledgements. Study was funded by Latvian Council of Science project "Adaptive capacity of forest trees and possibilities to improve it" (No 454/2012) and "Forest tree breeding for establishment of high genetic quality stands".

\section{References}

Adamson, K., Klavina, D., Drenkhan, R., Gaitnieks, T., Hanso, M. 2015. Diplodia sapinea is colonizing the native Scots pine (Pinus sylvestris) in the northern Baltics. - European Journal of Plant Pathology, 143(2), 343-350.

Baumanis, I. 1983. The impact of geograpfical origin to resistance of pine. (Влияние географического происхождения на резистетентность сосны). Ермаков, В.И., Щербакова, М.А., Этверк, И.Э., Пугач, Е.А., Тихова, М.А. (eds.). Proceedings of conference on forest genetics, tree breeding and seed production. (Тезиси докладов Всесоюзное совещание по лесной генетике, селекции и семеноводству), 1-4 November 1983, Petrozavodsk, Russia, 114-116. (In Russian).

Baumanis, I. 1993. A complex research project: Factors in Latvia affecting the health of pine (Planting stock and young plantations), and recommended protective measures. - Proceeding of the Latvian Academy of Sciences, 7(552), 79-80.

Bednářová, M., Dvořák, M., Janoušek, J., Jankovský, L. 2013. Other foliar diseases of coniferous trees. - Gonthier, P., Nicolotti, G. (eds.). Infectious Forest Diseases. CABI: Wallingford, UK; Boston, MA, 458-487.

Björkmann, E. 1964. Breeding for resistance to disease in forest trees. - Unasylva, 18, 71-81.

Bušs, K. 1976. Forest classification in Latvian SSR. (Latvijas PSR meža tipoloǵijas pamati). Silava, Riga. 24 pp. (In Latvian).

Bušs, M., Mangalis, I. 1971. Forest regeneration. (Meža kultūras). Zvaigzne, Riga. 586 pp.

Clark, J. 1961. Photosynthesis and respiration in white spruce and balsam fir. State University of New York, College of Forestry, Syracuse, N.Y. 72 pp.

Drenkhan, R., Hanso, M. 2009. Recent invasion of foliage fungi of pines (Pinus spp.) to the Northern Baltics. - Forestry Studies / Metsanduslikud Uurimused, 51, 49-64.

Drenkhan, R., Kurkela, T., Hanso, M. 2006. The relationship between the needle age and the growth rate in Scots pine (Pinus sylvestris): A retrospective analysis by needle trace method (NTM). - European Journal of Forest Research, 125(4), 397-405.

Drenkhan, R., Tomešová-Haataja, V., Fraser, S., Bradshaw, R.E., Vahalík, P., Mullett, M.S., MartínGarcía, J., Bulman, L.S., Wingfield, M.J., Kirisits, T., Cech, T.L., Schmitz, S., Baden, R., Tubby, K.,
Brown, A., Georgieva, M., Woods, A., Ahumada, R., Jankovský, L., Thomsen, I.M., Adamson, K., Marçais, B., Vuorinen, M., Tsopelas, P., Koltay, A., Halasz, A., La Porta, N., Anselmi, N., Kiesnere, R., Markovskaja, S., Kačergius, A., Papazova-Anakieva, I., Risteski, M., Sotirovski, K., Lazarević, J., Solheim, H., Boroń, P., Bragança, H., Chira, D., Musolin, D.L, Selikhovkin, A.V., Bulgakov, T.S., Keča, N., Karadžić, D., Galovic, V., Pap, P., Markovic, M., Poljakovic Pajnik, L., Vasic, V., Ondrušková, E., Piškur, B., Sadiković, D., Diez, J.J., Solla, A., Millberg, H., Stenlid, J., Angst, A., Queloz, V., Lehtijärvi, A., Doğmuş-Lehtijärvi, H.T., Oskay, F., Davydenko, K., Meshkova, V., Craig, D., Woodward, S., Barnes, I. 2016. Global geographic distribution and host range of Dothistroma species: a comprehensive review. - Forest Pathology, 46, 408-442.

Ericsson, A., Larsson, S., Tenow, O. 1980. Effects of early and late season defoliation on growth and carbohydrate dynamics in Scots pine. - Journal of Applied Ecology, 17, 747-769.

Eriksson, G., Ekberg, I., Clapham, D. 2013. Genetics Applied to Forestry - An Introduction. Third edition. Uppsala, Department of Plant Biology and Forest Genetics, Swedish University of Agricultural Sciences. 208 pp.

Hanso, M., Drenkhan, R. 2007. Retrospective analysis of Lophodermium seditiosum epidemics in Estonia. - Acta Silvatica Lignaria Hungarica, Special Edition, 31-45.

Hanso, M., Drenkhan, R. 2012. Lophodermium needle cast, insect defoliation and growth responses of young Scots pines in Estonia. - Forest Pathology, 42,124-135.

Jansons, Ā. 2005. Distinguishing between the effect of seed material and forest type on Scots pine stand productivity. - Gaile, Z. (ed.). Proceedings of the international scientific conference Research for Rural Development, LLU, Jelgava, Latvia, 227-233.

Jansons, Ā., Baumanis, I., Dreimanis, A., Gailis, A. 2006. Variability and genetic determination of Scots pine quantitative traits at the age of 32 years. - Gaile, Z. (ed.). Proceedings of the international scientific conference Research for Rural Development, LLU, Jelgava, Latvia, 289-295.

Jansons, Ā., Jansons, J., Baumanis, I., Rieksts-Riekstins, J. 2012. Assessment of needle cast resistance in young Scots pine plantations in Latvia. - Proceedings of 8th WSEAS International Conference on Energy, Environment, Ecosystems and Sustainable Development (EEESD '12), Faro, Portugal, May 2012, 111-115.

Jansons, Á., Neimane, U., Baumanis, I. 2008. Scots pine needlecast resistance and its potential improvements. (Parastās priedes skujbires rezistence un tās paaugstināšanas iespējas). - Mežzinātne (Forest Science), 18, 3-18. (In Latvian).

Jansson, G., Hansen, J.K., Haapanen, M., Kvaalen, H., Steffenrem, A. 2016. The genetic and economic gains from forest tree breeding programs in Scan- 
dinavia and Finland. - Scandinavian Journal of Forest Research, 1-42.

Johnson, G.R. 2002. Genetic variation in tolerance of Douglas-fir to Swiss needle cast. - Silvae Genetica, 51(2-3), 80-86.

Kulman, H.M. 1971. Effects of insect defoliation on growth and mortality of trees. - Annual Review of Entomology, 16, 289-324.

Kurkela, T., Drenkhan, R., Vourinen, M., Hanso, M. 2009. Growth response of young Scots pines to needle loss assessed from productive foliage. Forestry Studies / Metsanduslikud Uurimused, 50, 5-22.

Kuzmina, N., Kuzmin, S. 2008. Intraspecific response of Scots pine (Pinus sylvestris L.) to pathogens in a provenance trial in Middle Siberia. - Eurasian Journal of Forest Research, 11(2), 51-59.

Lilja, A., Poteri, M., Petäistö, R.-L., Rikala, R., Kurkela, T., Kasanen, R. 2010. Fungal diseases in forest nurseries in Finland. - Silva Fennica, 44(3), 525-545.

Lyr, H., Hoffmann, G. 1967. Growth rates and growth periodicity of the roots. - International Review of Forestry Research, 2, 181-236.

Lyytikäinen-Saarenmaa, P. 1999. The responses of Scots pine, Pinus sylvestris, to natural and artificial defoliation stress. - Ecological Applications, 9(2), 469-474.

Martinsson, O. 1979. Testing Scots pine for resistance to Lophodermium needle cast. - Studia Forestalia Suecica, 150, 63 pp.

Ostry, M.E., Nicholls, T.H. 1989. Effect of Lophodermium seditiosum on growth of pine nursery seedlings in Wisconsin. - Plant Disease, 73(10), 798-800.

Report of LVM (Joint Stock Company "Latvia's State Forests"). 2015. [WWW document]. - URL http:/ / www.lvm.lv/mezsaimniecibas-cikls/meza-kopsana [Accessed 26 September 2016].

Report of State Forest Service, 2015. [WWW document]. - URL http://www.vmd.gov.lv/valstsmeza-dienests/statiskas-lapas/publikacijas-unstatistika?nid=1717\#jump [Accessed 29 September 2016].

Shaw, C.G.III, Toes, E.H.A. 1977. Impact of Dothistroma needle blight and Armillaria root rot on diameter growth of Pinus radiata. - Phytopathology, 67, 1319-1323.

Šmits, A., Strikse, Z., Liepa, I. 2008. Effect of defoliation caused by European pine sawfly (Neodiprion sertifer
Geoffr.) on Scots pine (Pinus sylvestris L.). (Priežu rūsganās zāğlapsenes (Neodiprion sertifer Geoffr.) izraisītās defoliācijas ietekme uz priežu (Pinus sylvestris L.) pieaugumu). - Mežzinātne (Forest Science), 18, 53-73. (In Latvian).

Squillace, A.E., La Bastide, J.G.A., van Vredenburch, C.L.H. 1975. Genetic variation and breeding of Scots pine in the Netherlands. - Forest Science, 21(4), 341-352.

Stenström, E., Arvidsson, B. 2001. Fungicidal control of Lophodermium seditiosum on Pinus sylvestris seedlings in Swedish forest nurseries. - Scandinavian Journal of Forest Research, 16, 147-154.

Stephan, B.R., Krusche, D. 1986. Genetic variation of resistance to Lophodermium needle cast in Scots pine progenies of intraprovenance and interprovenance crossings. - Recent research on conifer needle diseases, proceedings, Gulfport, Mississippi, October 1984, 28-34.

Temel, F. 2002. Early testing of Douglas-fir (Pseudotsuga menziesii var. menziesii (Mirb.) Franco) for Swiss needle cast tolerance. PhD Thesis. Oregon State University. 177 pp.

van der Pas, J.B. 1981. Reduced early growth rates of Pinus radiata caused by Dothistroma pini. - New Zealand Journal of Forestry Science, 11(3), 210-220.

Vuorinen, M. 2008. Climatic factors affecting the needlecast epidemics caused by Lophodermium seditiosum. - Adaptation of Forests and Forest Management to Changing Climate with Emphasis on Forest Health: A Review of Science, Policies and Practices, Book of Abstracts of International Scientific Conference, 25-28 August 2008, Umeå, Sweden, p. 259.

Williams, D.T., Straw, N.A., Day, K.R. 2003. Defoliation of Sitka spruce by the European spruce sawfly, Gilpinia hercyniae (Hartig): A retrospective analysis using the needle trace method. - Agricultural and Forest Entomology, 5(3), 235-245.

Wühlisch, G., von Stephan, B.R. 1986. Development of the progeny of Schleswig-Holstein Plus free withered trees of Pinus sylvestris L. under the age of 33 years. (Entwicklung der Nachkommenschaften frei abgeblühter schleswig-holsteinischer Plusbäume von Pinus sylvestris L. bis zum Alter von 33 Jahren). Allgemeine Forst und Jagdzeitung, 157, 117-124. (In German). 